\title{
PENGARUH RASIO MOL, SUHU DAN LAMA REAKSI TERHADAP BILANGAN IOD, BILANGAN ASAM, BILANGAN PEROKSIDA DAN KANDUNGAN SULFONAT SURFAKTAN DARI CPO
}

\author{
Sri Hidayati ${ }^{1}$ dan Illim² \\ ${ }^{1}$ Staf Pengajar Jurusan Teknologi Hasil Pertanian, Unila \\ ${ }^{2}$ Staf Pengajar Jurusan Kimia, Unila
}

\begin{abstract}
A surfactant is a surface-active agent that can be produced by chemical or biochemical synthesis. The main characteristic of a surfactant is having polar and non polar groups at the same molecule (amphiphilic molecules) and forming head-tail configuration. This research as aimed to obtain the optimum condition (reaction temperature, sulphonation reaction and molar ratio) of sulphonation process in producing MES from CPO methyl ester and to investigate the characteristic of MES produced. Measurements conducted include iodine value, acid value, peroxide value and absorbance of Sulfonate. Experimental design used was Response Surface Method (RSM) and Central Composite Design (CCD) with three factors. MES resulted from this best condition had following characteristic or CPO was obtained with ratio of reactants of 1:1.5, reaction time of 4.5 hour and reaction temperature of $108.9^{\circ} \mathrm{C}$ with Acid value of $13.32 \mathrm{mg} \mathrm{KOH} / \mathrm{g}$ sample, Iod value of $41.12 \mathrm{Iod} \mathrm{g} / 100 \mathrm{sample}$, Peroxide value of $7.6 \mathrm{mmole} / 1000 \mathrm{~g}$, sulfonat absorbance of $0.76 \mathrm{AU}$.
\end{abstract}

Keywords : metil ester sulfonat, acid value, iod value, peroxide value

\section{PENDAHULUAN}

Surfaktan atau surfactant berasal dari akronim surface active agent merupakan suatu molekul amphipatic atau amphiphilic yang mengandung gugus hidrofilik dan lipofilik dalam satu molekul yang sama. Sifat-sifat surfaktan adalah mampu menurunkan tegangan permukaan, tegangan antarmuka, meningkatkan kestabilan partikel yang terdispersi dan mengontrol jenis formasi emulsi (misalnya oil in water $(\mathrm{O} / \mathrm{W})$ atau water in oil (W/O). Di samping itu, surfaktan akan terserap ke dalam permukaan partikel minyak atau air sebagai penghalang yang akan mengurangi atau menghambat penggabungan (coalescence) dari partikel yang terdispersi.

Bahan baku pembuatan surfaktan dapat diperoleh dari minyak bumi (fossil fuel) atau dari minyak nabati dan hewani. Kelemahan surfaktan dari minyak bumi adalah bahan baku bersifat tidak dapat diperbarui, harga mahal, tidak tahan pada kesadahan tinggi, dan sulit didegredasi oleh mikroba sehingga tidak ramah lingkungan. Sumber keunggulan surfaktan MES yang berasal dari bahan baku minyak nabati atau hewani adalah bahan bakunya bersifat renewable (terbarukan), murah, ramah lingkungan, secara alami mudah didegradasi, bersinergi baik dengan sabun, daya larut yang baik, lembut dan tidak iritasi pada kulit, dan memiliki sifat deterjensi yang baik walaupun digunakan pada air dengan tingkat kesadahan dan salinitas yang cukup tinggi.

Metil Ester Sulfonat (MES) merupakan salah satu surfaktan anionik yang berfungsi sebagai bahan aktif penurun tegangan permukaan suatu larutan. Sumber bahan baku metil ester dari minyak nabati sebagai bahan pembuatan surfaktan dapat berasal dari tanaman edible food maupun non edible food seperti kelapa, kelapa sawit, kacang, kelor, jarak, kapuk, dan berbagai tanaman lainnya yang menghasilkan komponen minyak trigliserida. Produksi metil ester sulfonat dari minyak sawit mempunyai prospek yang sangat baik karena mempunyai sifat yang lebih baik, murah, dan ramah lingkungan ${ }^{[1]}$.Metil ester sulfonat dari minyak 
nabati kelapa, PKO, stearin sawit, dan kedelai akan menjadi kompetitif produk baru ${ }^{[2]}$.

Faktor yang menentukan kualitas MES dari minyak nabati diantaranya adalah rasio molekul reaktan, suhu reaksi, konsentrasi gugus sulfat yang ditambahkan, bahan pengsulfonasi $\quad \mathrm{NaHSO}_{3}, \quad \mathrm{H}_{2} \mathrm{SO}_{4}, \quad \mathrm{SO}_{3}$, $\mathrm{NH}_{2} \mathrm{SO}_{3} \mathrm{H}$, maupun $\mathrm{ClSO}_{3} \mathrm{H}$ ), waktu netralisasi, $\mathrm{pH}$, dan suhu netralisasi ${ }^{[3]}$. Rasio mol reaktan merupakan salah satu faktor yang harus dikendalikan dalam proses sulfonasi untuk menghasilkan metil ester sulfonat. Rasio mol reaktan yang berlebihan akan menyebabkan reaksi samping terbentuknya garam yang tidak diinginkan.

Upaya menurunkan terbentuknya garam (disalt) dalam MES perlu dilakukan dengan proses pemurnian. Proses pemurnian MES sangat ditentukan oleh suhu dan konsentrasi metanol. Dengan demikian diperlukan pengaturan proses sulfonasi, waktu, suhu, dan konsentrasi metanol untuk menghasilkan MES yang optimal. Tujuan dari penelitian ini adalah mendapatkan kondisi proses sulfonasi yang optimum terhadap kandungan sulfonat MES dari metil ester CPO dan pengaruhnya terhadap bilangan iod, bilangan asam dan bilangan peroksida proses produksi metil ester sulfonat (MES).

\section{METODE PENELITIAN}

\section{Alat dan Bahan}

Peralatan yang digunakan dalam proses pembuatan Metil Ester Sulfonat adalah seperangkat reaktor sulfonasi, sentrifus, rotor penggerak, alat timbang dan alat analisis seperti kromatografi gas, dan alat analisis uji kimia. Bahan yang digunakan untuk penelitian adalah Metil ester CPO yang diperoleh dari BPPT Serpong. Bahan-bahan kimia yang digunakan adalah $\mathrm{NaHSO}_{3}$ teknis, metanol dan bahan kimia untuk analisis.

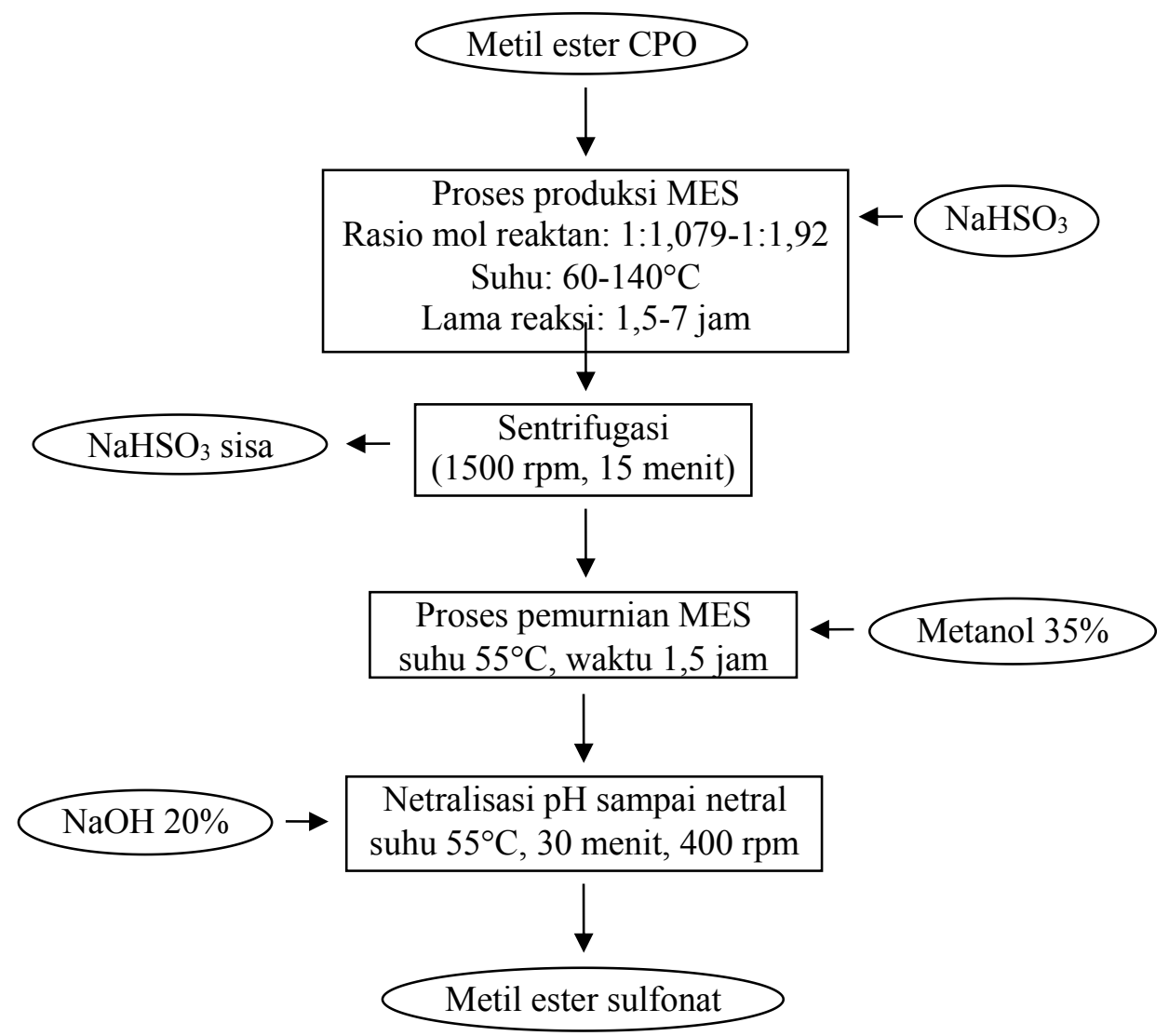

Gambar 1. Diagram alir proses produksi MES dari metil ester $\mathrm{CPO}$ menggunakan $\mathrm{NaHSO}_{3}{ }^{[2]}$ 


\section{Pembuatan Metil Ester Sulfonat dari Metil Ester CPO}

Pada penelitian ini dilakukan optimasi terhadap rasio mol reaktan $\mathrm{Na}$ bisulfit, lama reaksi dan suhu sulfonasi dengan menggunakan $\mathrm{NaHSO}_{3}$ sebagai bahan pensulfonasi. Perlakuan yang digunakan adalah rasio mol reaktan $(1: 1,079-1: 1,96)^{[2]}$, lama reaksi (2-7 jam) dan suhu reaksi (60$140 \circ \mathrm{C})^{[4]}$, setelah itu dilakukan proses pemurnian dengan menggunakan metanol $35 \%{ }^{[2]}$ pada suhu $55^{\circ} \mathrm{C}$ selama $1,5 \mathrm{jam}^{[5]}$ dan dilakukan netralisasi dengan $\mathrm{NaOH} \quad 20 \%$ dengan suhu $55^{\circ} \mathrm{C}$ selama 0,5 jam ${ }^{[4]}$. Analisis yang dilakukan terhadap produk yang dihasilkan meliputi bilangan iod, bilangan asam, bilangan peroksida, peroksida ${ }^{[6]}$, uji absorbansi sulfonat dengan spektrometer UV-Visible dan uji kualitatif untuk mendeteksi keberadaan gugus sulfonat dengan Fourier Transform Infra Red (FTIR).
Desain eksperimen dan analisis hasil optimasi variabel proses dilakukan dengan menggunakan Central Composite Design dan Response Surface Methode (RSM).

\section{HASIL DAN PEMBAHASAN}

Pengaruh Rasio Mol, Lama Reaksi dan Suhu Reaksi terhadap Absorbansi pada MES

Hasil pada rancangan faktorial dan titik pusat menunjukkan respon absorbansi yang dihasilkan oleh proses sulfonasi metil ester berbasis CPO pada penelitian ini berkisar antara 0,3-0,74 sampel. Hasil analisis keragaman menunjukkan bahwa kandungan sulfonat pada MES berbasis metil ester dari CPO hasil sulfonasi dipengaruhi oleh interaksi suhu dan lama reaksi (Gambar 2 dan 3).

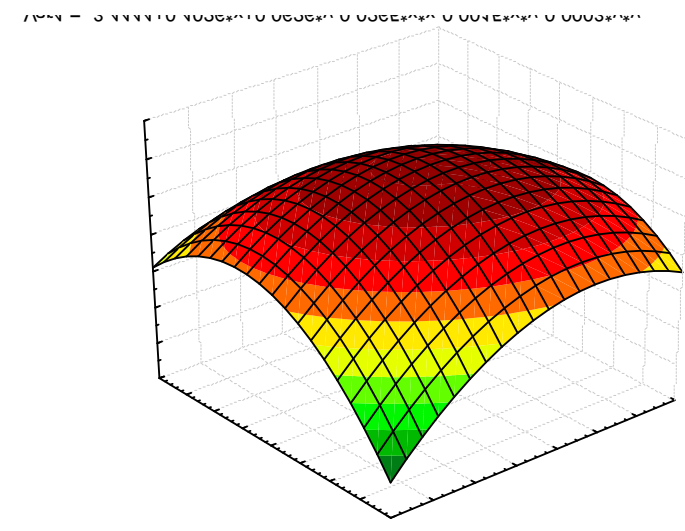

Absorbansi

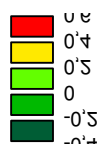

Gambar 2. Permukaan respon perolehan absorbansi sebagai fungsi dari lama reaksi dan suhu sulfonasi pada MES

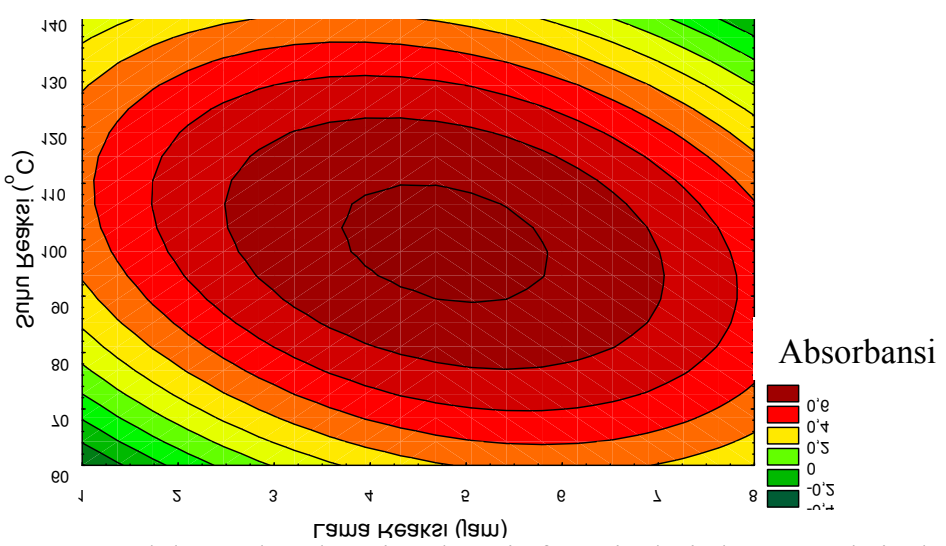

Gambar 3. Kontur respon perolehan absorbansi sebagai fungsi dari lama reaksi dan suhu sulfonasi pada MES 
Nilai absorbansi sulfonat tertinggi yaitu 0,76 diperoleh pada suhu sulfonasi antara $90-100^{\circ} \mathrm{C}$ dan lama reaksi antara 4-5 jam. Pada kondisi proses ini nilai bilangan iod menunjukkan angka yang paling rendah yaitu $<15 \mathrm{mg}$ $\mathrm{KOH} / 100 \mathrm{~g}$ sampel. Nilai bilangan iod menunjukkan keberhasilan adisi metil ester oleh gugus sulfonat sehingga meningkatkan kandungan sulfonat yang berimplikasi pada peningkatan absorbansi sulfonat.

Pengaruh Rasio Mol, Lama Reaksi dan Suhu Reaksi terhadap Bilangan Iod pada MES dari Metil Ester $\mathbf{C}_{16}$ berbasis CPO

Hasil pada rancangan faktorial dan titik pusat menunjukkan respon bilangan iod yang dihasilkan oleh proses sulfonasi pada penelitian ini berkisar antara 35,56 - 49,98 g $\mathrm{iod} / 100 \mathrm{~g}$ sampel. Hasil analisis keragaman menunjukkan bahwa bilangan iod pada penggunaan MES dipengaruhi oleh lama reaksi dan interaksi rasio mol dan suhu reaksi. Peningkatan lama reaksi $>6$ jam, rasio mol $>1: 1,5$ dan suhu reaksi $>110^{\circ} \mathrm{C}$ akan menyebabkan penurunan bilangan iod pada MES dari metil ester CPO (Gambar 4 dan 5). Hal ini diduga karena metil ester dari CPO memiliki kandungan karoten yang merupakan senyawa dengan 11 ikatan rangkap dua sehingga mudah teroksidasi oleh panas dan ikut teradisi oleh Na-bisulfit. Proses ini memerlukan reaktan, suhu dan lama reaksi yang lebih besar untuk menurunkan bilangan iod.

Bilangan Iod g
I2/100 g sampel

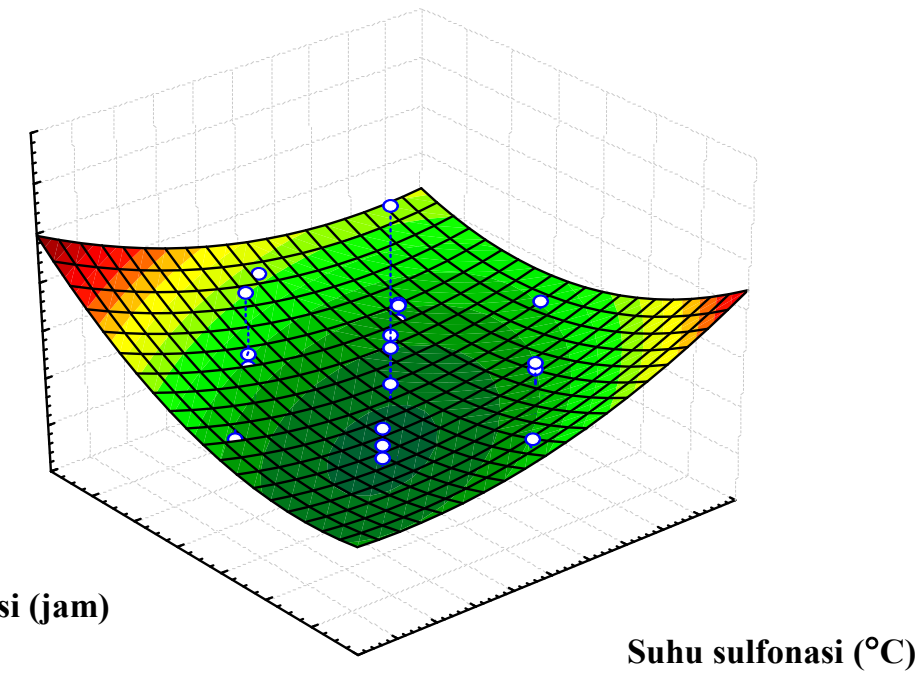

Suhu sulfonasi $\left({ }^{\circ} \mathrm{C}\right)$

Gambar 4. Respon permukaan bilangan Iod sebagai fungsi dari lama reaksi dan suhu sulfonasi pada MES dari metil ester PKO

Lama reaksi (jam)

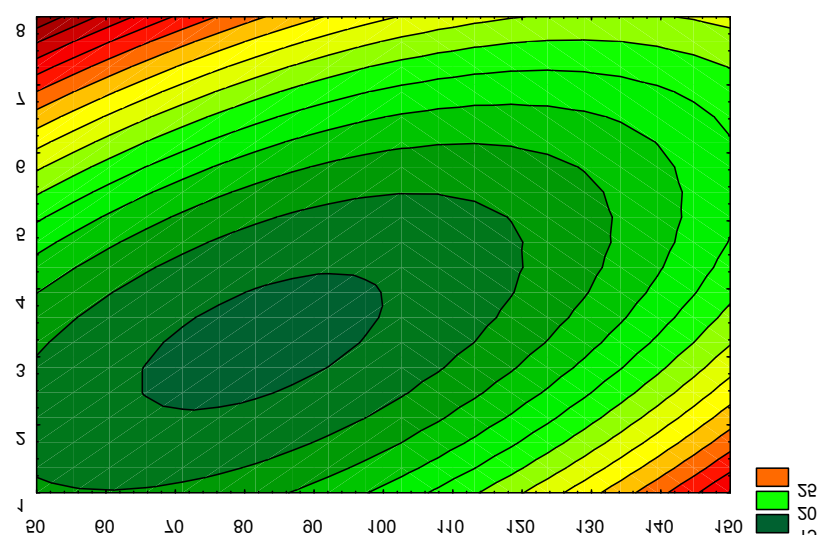

Suhu sulfonasi $\left({ }^{\circ} \mathrm{C}\right)$

Gambar 5. Kontur respon nilai bilangan Iod sebagai fungsi dari lama reaksi dan suhu sulfonasi pada MES dari metil ester PKO 
Pengaruh Rasio Mol, Lama Reaksi dan Suhu Reaksi terhadap Bilangan Peroksida pada MES dari Metil Ester $\mathrm{C}_{16}$ berbasis CPO

Hasil pada rancangan faktorial dan titik pusat menunjukkan respon bilangan peroksida yang dihasilkan oleh proses sulfonasi pada penelitian ini berkisar antara 8,61-16,91 $\mathrm{mmol} / 1000 \mathrm{~g}$ sampel. Hasil analisis keragaman menunjukkan bahwa bilangan peroksida pada penggunaan MES dipengaruhi oleh lama reaksi dan suhu reaksi. Semakin tinggi suhu reaksi dan lama reaksi akan meningkatkan bilangan peroksida (Gambar 6 dan 7).

Peningkatan pembentukan peroksida akan dipercepat oleh suhu dan lama waktu reaksi
(Gambar 3 dan 4). Hal ini diduga bahwa semakin tinggi suhu $\left(>120^{\circ} \mathrm{C}\right)$ dan lama reaksi ( $>5$ jam) akan meningkatkan laju oksidasi MES. Oksidasi metil ester dimulai dengan pembentukan peroksida dan hidroperoksida. Pore menyatakan bahwa oksidasi menggunakan Na-bisulfit dalam waktu yang lama akan meningkatkan peroksida akibat proses epoksidasi ikatan rangka dari hidroperoksida ${ }^{[4]}$. Bilangan peroksida adalah nilai terpenting untuk menentukan derajat kerusakan pada minyak atau lemak. Asam lemak tidak jenuh dapat mengikat oksigen pada ikatan rangkapnya sehingga membentuk peroksida. Pembentukan peroksida akan semakin meningkat dengan tingginya derajat ketidak jenuhan minyak.

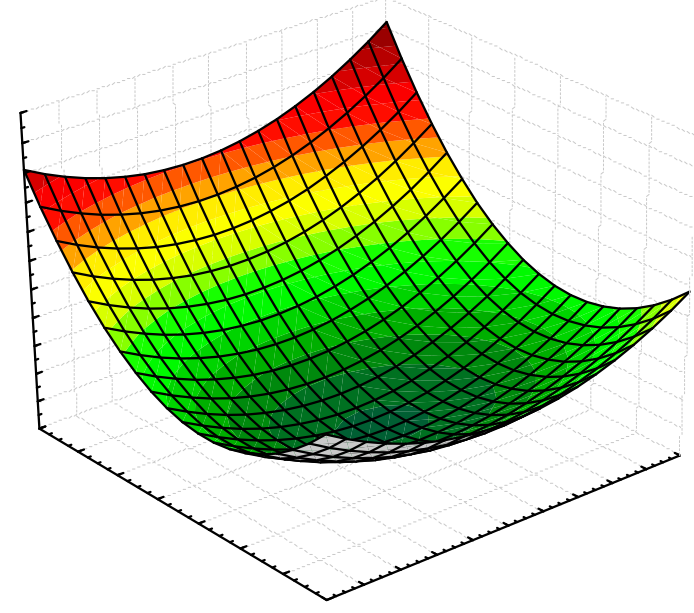

Bilangan peroksida $\mathrm{mmol} / 1000 \mathrm{~g}$ lemak

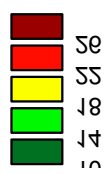

Gambar 6. Permukaan respon bilangan peroksida sebagai fungsi dari rasio mol dan lama reaksi pada MES

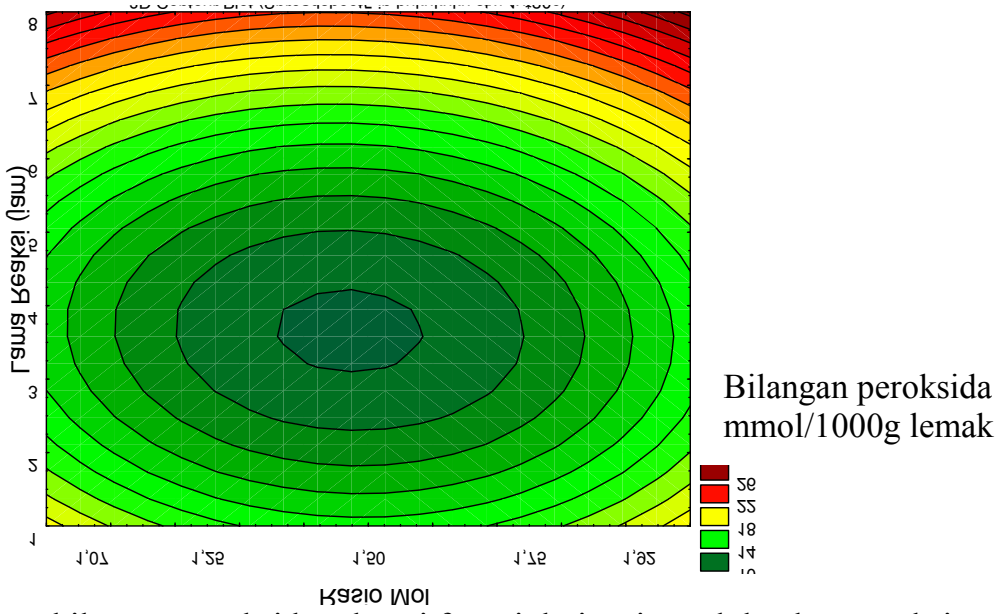

Gambar 7. Permukaan respon bilangan peroksida sebagai fungsi dari rasio mol dan lama reaksi pada MES 


\section{Pengaruh Rasio Mol, Lama Reaksi dan Suhu Reaksi terhadap Asam pada MES}

Bilangan asam adalah bilangan yang menunjukkan banyaknya miligram $\mathrm{KOH}$ yang diperlukan untuk menetralkan satu gram lemak atau minyak. Ketika Na-bisulfit digunakan dalam proses sulfonasi maka akan meningkatkan bilangan asam. Bilangan asam yang dihasilkan oleh proses sulfonasi metil ester CPO berkisar 7,6-14,62 $\mathrm{mg} \mathrm{KOH} / \mathrm{g}$ sampel. Hasil analisis statistik menunjukkan bahwa bilangan asam pada MES berbasis metil ester CPO dipengaruhi oleh rasio mol, lama reaksi dan suhu reaksi. Semua faktor ini mempunyai pengaruh yang positif terhadap peningkatan bilangan asam. Hal ini diperkirakan bahwa peningkatan suhu $>120^{\circ} \mathrm{C}$, lama reaksi $>6$ jam dan rasio mol $>1: 1,65$ akan meningkatkan bilangan asam (Gambar 8 dan 9).

Peningkatan suhu dan lama reaksi akan menyebabkan peningkatan pembentukan sulfon dan reaksi samping seperti asam-asam berantai pendek, pada degradasi yang lebih lanjut akan menghasilkan pembentukan asam sulfur yang menyebabkan penurunan bilangan $\operatorname{asam}^{[7,8,9]}$.

\section{Bilangan Asam (mg KOH/g sampel)}

Suhu reaksi $\left({ }^{\circ} \mathrm{C}\right)$
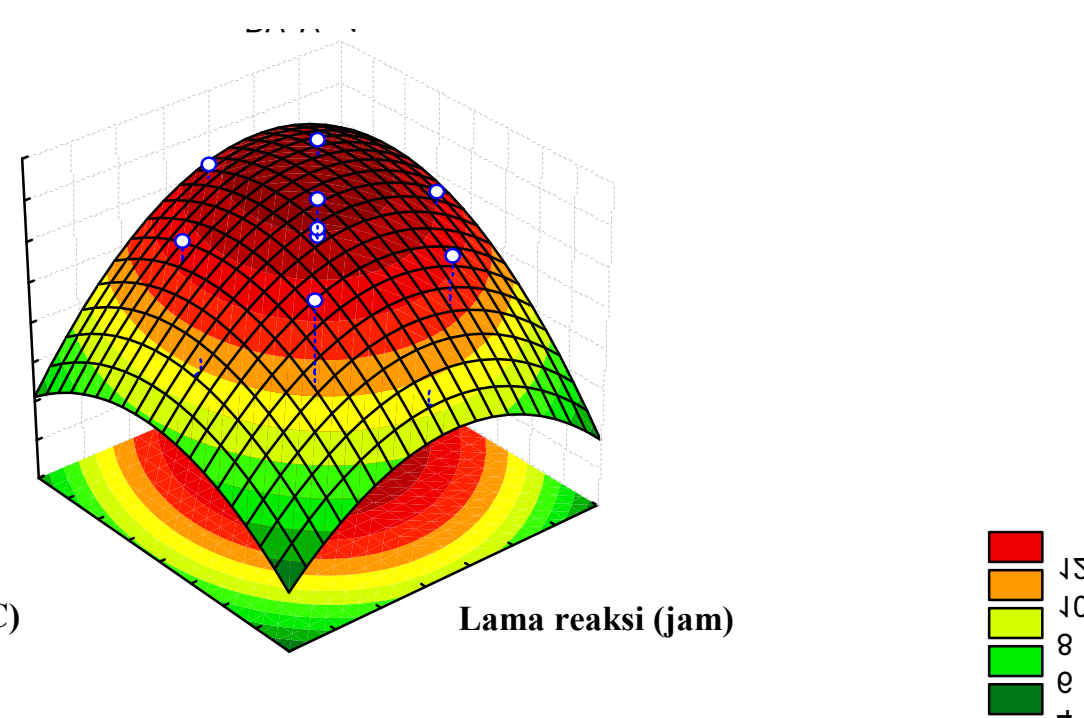

Gambar 8. Respon permukaan bilangan Asam sebagai fungsi dari lama reaksi dan suhu reaksi pada MES dari metil ester CPO

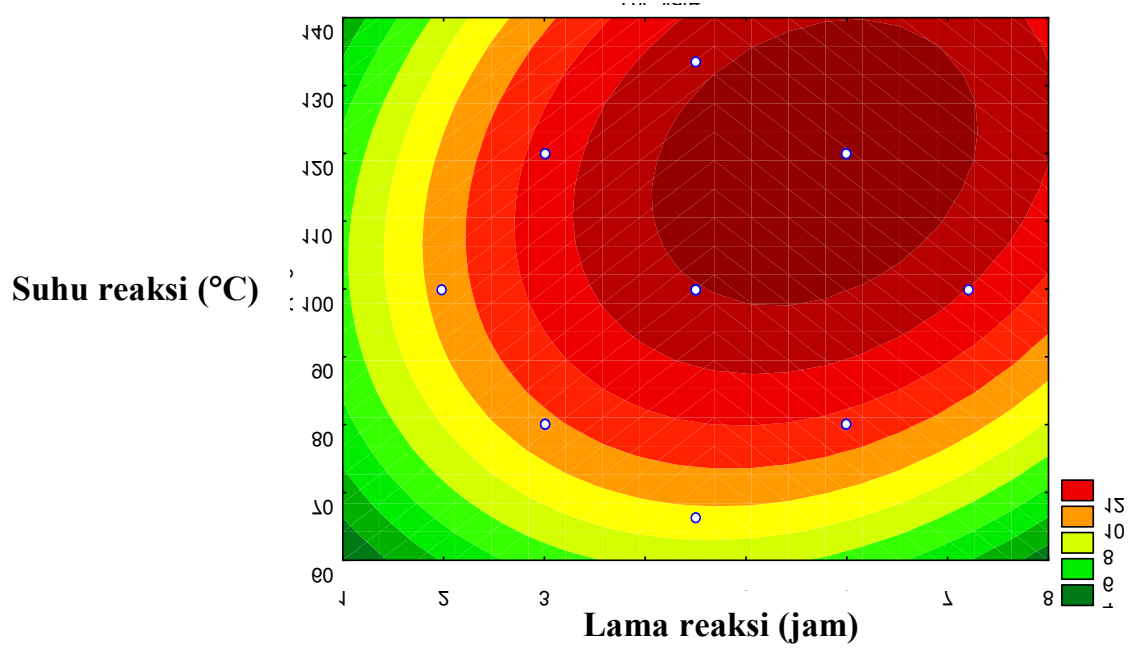

Gambar 9. Kontur respon bilangan Asam sebagai fungsi dari lama reaksi dan suhu reaksi pada MES dari metil ester $\mathrm{CPO}$ 


\section{Gugus Sulfonat dari MES yang dihasilkan}

Spektrum infra merah terletak pada daerah dengan panjang gelombang berkisar 0,78 sampai $1000 \mathrm{~nm}$ atau bilangan gelombang dari 12800 sampai $10^{-7} \mathrm{~cm}^{-1}$. Aplikasi spektroskopi inframerah sangat luas baik untuk analisis kualitatif maupun kuantitatif. Penggunaan yang paling banyak adalah pada daerah pertengahan dengan kisaran bilangan gelombang 4000 sampai $670 \mathrm{~cm}^{-1}$. Kegunaan yang paling penting adalah untuk identifikasi senyawa-senyawa organik ${ }^{[10]}$.

Menurut Mukherji, pendeteksian gugus sulfonat dengan menggunakan spektrum infra merah dikarakterisasi oleh regangan getaran molekul $\mathrm{O}-\mathrm{H}$ dan $\mathrm{S}=\mathrm{O}^{[11]}$. Penampakan regangan pada daerah dengan bilangan gelombang 3460-3100 $\mathrm{cm}^{-1}$ ditetapkan sebagai $\mathrm{O}-\mathrm{H}$ sedangkan regangan vibrasi $\mathrm{S}=\mathrm{O}$ yang simetris ditampakkan pada bilangan gelombang 1342-1250 $\mathrm{cm}^{-1}$.

Peesok menyatakan bahwa gugus sulfonat ionik dideteksi pada bilangan gelombang $1250-1150_{(\mathrm{s})} \mathrm{cm}^{-1}$ dan $1075-1000_{(\mathrm{m})} \mathrm{cm}^{-1}$, sedang dari ASTM (2001) (D 2357-74) gugus sulfonat dihasilkan pada bilangan gelombang 1235 sampai $1176 \mathrm{~cm}^{-1}{ }^{[12]}$. Metil Ester
Sulfonat (MES) dari metil metil ester dari CPO yang tidak dipanaskan, gugus sulfonat diperlihatkan pada bilangan gelombang 1235 sampai $1172 \mathrm{~cm}^{-1}, \quad \mathrm{~S}=\mathrm{O}$ pada bilangan gelombang $1029,1 \mathrm{~cm}^{-1}$ dan golongan alkohol pada bilangan gelombang $3600-3200 \mathrm{~cm}^{-1}$ (Gambar 10).

\section{KESIMPULAN}

Hasil optimasi proses pembuatan MES berbahan baku metil ester dari CPO menunjukkan bahwa kondisi kombinasi perlakuan rasio mol, suhu reaksi dan lama reaksi dengan menggunakan hasil analisis metode permukaan respon berpengaruh nyata terhadap kadar iod, kadar asam dan kadar peroksida MES yang dihasilkan. Kondisi optimum proses sulfonasi dari metil ester CPO diperoleh pada rasio mol pada rasio mol 1:1,5, lama reaksi 4,5 jam dan suhu reaksi $108,9^{\circ} \mathrm{C}$ yang menghasilkan nilai absorbansi sulfonat $0,76 \mathrm{AU}$, bilangan asam 13,32 $\mathrm{mg} \mathrm{KOH} / \mathrm{g}$ sampel, bilangan iod 41,12 g Iod/100 g sampel dan bilangan peroksida $7,6 \mathrm{mmol} / 1000$ gram dan terjadi pembentukan gugus sulfonat yang diperlihatkan pada bilangan gelombang 1235 sampai $1172 \mathrm{~cm}^{-1}$.

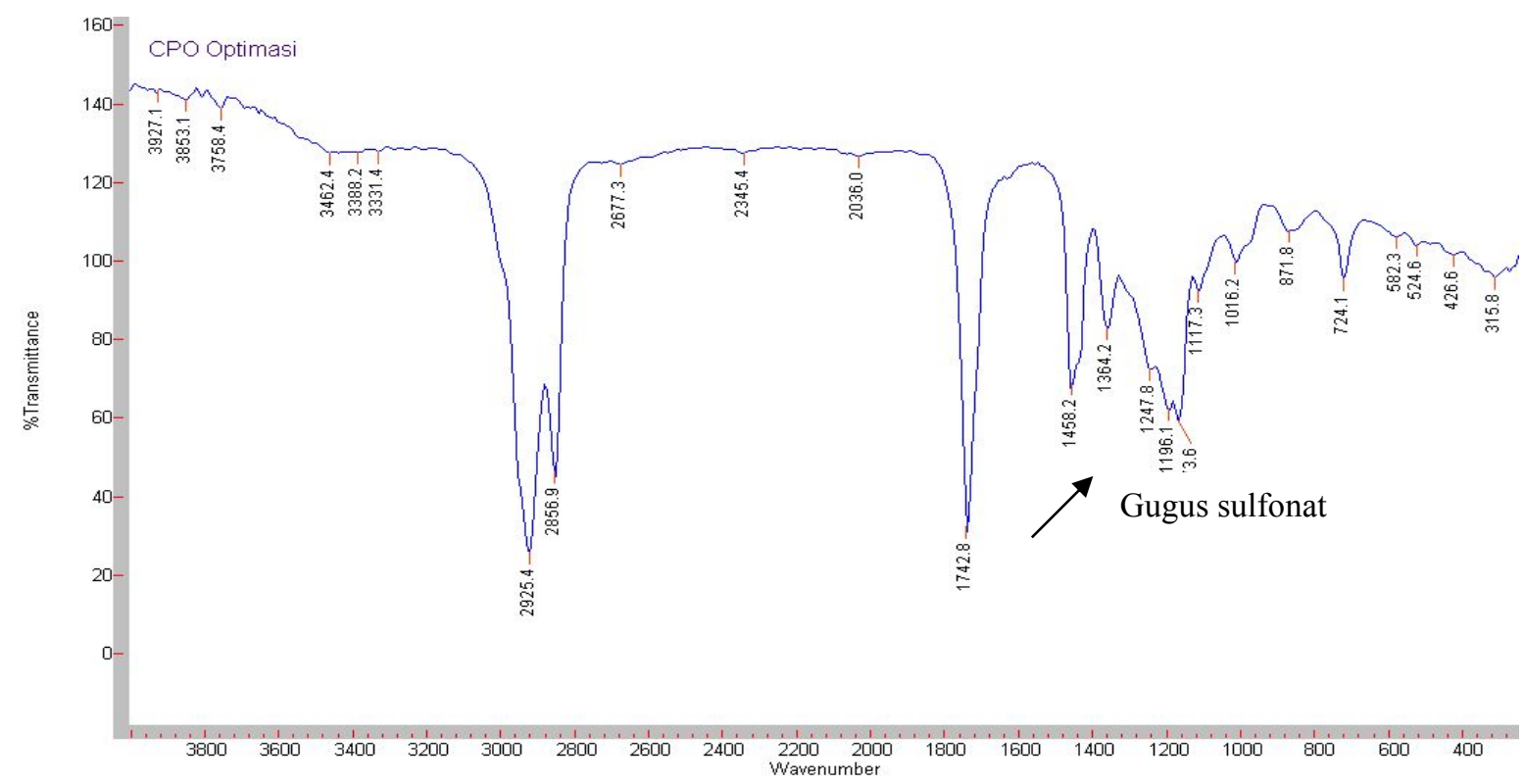

Gambar 10. Analisis gugus sulfonat pada metil ester sulfonat dari metil ester CPO yang diuji dengan menggunakan FTIR 


\section{DAFTAR PUSTAKA}

1. E. Hambali, A. Suryani, D. Haryadi, H. Hanafie, I. K. Reksowardoyo, M. Rivai, M. Ihsanur, P. Suryadarma, S. Tjitrosemito, T. H. Soerawidjaja, T. Pawitasari, T. Praksoso, dan W. Purnama, Jarak pagar tanaman penghasil biodiesel, Swadaya, 2006, 147.

2. W. B. Sheats, dan B. W. Mac Arthur, Methyl Ester Sulfonate Products, [terhubung berkala, http://www.chemithon.com, (26/2/2003).

3. C. Foster, Sulfonation and Sulfation Processes. In : Soap and Detergents, A Theoretical and Practical Review, Spitz, L, JAOCS., Champaign, Illinois, (1996).

4. J. Pore, Oil and Fat Manual, Intercept Ltd, Andover, UK, Paris, New York, 1993.

5. A. E. Sherry, B. E. Chapman, M. T. Creedon, J. M. Jordan, dan R. L. Moese, Nonbleach Process for the Purification of Palm C16-18 Methyl Ester Sulfonates, $J$. Am. Oil Chem., 72(7): 835-841, (1995).

6. AOAC, Official Method of Analysis of the Association of Official Analytical Chemist, AOAC, Washington, 1995.
7. J. B. Moreno, dan J. L Berna, Influence of Sulfonated Material and Its Sulfone Content on the Physical Properties of Linier Alkyl Benzene Sulfonates, JAOCS., 65(6), (1988).

8. P. C. Hu, dan M. E. Tuvell, Effect of Water Hardness Ions on the Solution Properties of an Anionic Surfactant, JAOCS., 65(8), (1988).

9. P. C. Hu, dan M. E. Tuvell, A Mechanistic Approach to the Thermal Degradation of $\alpha$ Olefin Sulfonates, JAOCS., 65(6), (1988).

10. Dunn, Effect of Oxidation Under Accelerated Conditions on Fuel Properties of Methyl Soya (biodiesel), JAOCS., 79(9), (2002).

11. R. M. Silverstein, and F. X Webster,. Spectrometric Identification Organic Compound, John Willey \& Sons, Inc, New York, 1988.

12. S. M. Mukherji, S. P Singh dan R. P Kapoor, Organic Chemistry, 2, New Age International, Limited Publ, New Dehli, 1985.

13. R. L. Peesok, L. D Shields, T. Courns dan I. G. Mac William, Modern Method of Chemical Analysis, $2^{\text {nd }}$ Editian, John Willey \& Sons, Inc, New York, 1976. 